\title{
The Nature of Tabloidized Content in Newspapers: An Overview
}

\author{
Divya Jyoti Randev
}

\begin{abstract}
Several newspapers around the world are increasingly attempting to adapt to the stiff competition with other newspapers and with the media industry as a whole. This has pushed them to target both the elite and the mass audiences, a move that has considerably changed their content and tone. To grab a greater share of readers, newspapers are also adopting somewhat controversial techniques of presentation of news that are used by tabloids. These include sensationalism, fabrication, simplification and the bold use of type, colour and imagery. They are also not shying away from glorifying grief and obscenity and have reduced their emphasis on verification.
\end{abstract}

Keywords: Tabloid, Tabloidization, Sensationalism, Fabrication, Personalization

\section{Introduction}

Tabloidization of the press has for long been a topic of discussion among media professionals. While the readers have been known to prefer tabloidized, less serious content, the journalists, press proprietors and news designers have been known to create and encourage it. The yellow journalism that began with Pulitzer and Hearst has found solid ground in print media today.

Newspapers carry bold and flashy headlines and splash their front pages with colour, scandals and frills. While a few years ago, it was easy to distinguish between a tabloid and a regular broadsheet through their size, content and design, presently, the differences have been diminishing.

Pieces and the tone of news that were earlier restricted to the magazine section, supplements and the entertainment section of a newspaper, have found their way on to the front page. Broadsheets therefore, can be said to resemble magazines today.

An International Colloquium held at New Delhi in 2011 for the promotion of universal respect for and observance of human rights and fundamental freedoms recommended that 'in pursuit of commercial interests media must avoid sensationalism or trivialization of issues' (Press Council of India annual report, 2011-12).

Journalism training course syllabi unfailing include the basic principles of the subject, one of which is respecting and adhering to the facts. It is, therefore, surprising to see that these very students of Journalism, when they enter the industry, resort to the techniques of sensationalism, invention of facts and the lack of verification in order to create attractive pieces of content.

N. Ram, the former Editor-in-Chief of The Hindu spoke about sensationalism, tabloidization, trivialization, celebrity-worship and the unchecked use of hidden cameras in the Indian news media. He said that this was "the real challenge before us," and that freedom without accountability and social responsibility would weaken the position of the media in society ('Balancing Freedom', Kumar, 2006).

Increasing competition to the newspapers from television and the Internet has been an important factor in pushing the respectable press to change its form and content to appeal to a wider audience than just having to cater to the educated reader looking for serious news. This is significant as the number of newspapers bought on impulse is more than purchases based on habit (McGrath, 2003). A reader buys what he finds interesting on the news stand.

When tools and techniques, such as sensationalism, fake news, deception, heightened emotionalism, obscenity and more visual imagery are used, they are employed to cater to a section of the audience that does not need or demand serious content.

As stated by Colin Sparks (also cited in Williams, 2003), "While there may be more information available, the quality of this information as well as public understanding is declining. Public ignorance and apathy is growing as the serious, challenging and truthful is being pushed aside by the trivial, sensational, vulgar and manipulated."

\section{Tabloidized Content}

Colin Sparks (2000) defines the nature of a tabloid as follows:

"It devotes relatively little attention to politics, economics and society and relatively much to diversions like sports, scandal and popular entertainment; it devotes relatively much attention to the personal and private lives of people, both celebrities and ordinary people, and relatively little to political processes, economic developments and social changes." 
Colin Sparks (2010) later writes, "The high standards of yesterday are being undermined by sensationalism, prurience, triviality, malice, and plain, simple credulity."

Tabloidized content is a combination of news and entertainment. The presentation style is not very serious even though it is 'news'. Facts are presented in a manner that is as exciting as fiction. Bird (1992) explains that tabloids do not claim to be fiction, even if they do claim primarily to be entertainment. They do report on real people and events, and their staff members are journalists. She states that a tabloid connotes, "cheapness, shoddiness, the overflow of the capitalist commodity system... it connotes a superficial glitter designed to appeal to those whose tastes are ill-formed according to the dominant perspective."

Gripsrud (2000) writes, "They skirt journalistic ethics by using long-lens cameras, engaging in highspeed chases, paying for interviews and exclusive rights to information. Their stories are often fanciful, if not invented."

There is often a disregard for journalistic ethics when it comes to tabloidized content. Therefore, the journalistic community as well as the readers have often debated on whether such content is worthy of respect.

\section{The Audience}

Many authors agree that tabloidized content is created to appeal to the masses. At present, newspapers better understand the market forces and also the need to reach out to the maximum number. The more the readership, the more the advertisers. The more the advertisers, the more the need for a large readership. This process is cyclic.

The colonization of the mainstream media by tabloid values has led to the democratization of media as it includes the non-elite people, issues and values (Biressi and Nunn, 2008).

Gans (also cited in Serazio, 2009) mentions the term 'popularization' and states, "After all, other cultural products have long been adapted for the simplified palates of a lower class strata." There is therefore, a distinction made between the lower and upper strata of readers. Gans (1999) has distinguished between high culture, upper middle class culture and a combination of middle and low culture known as the popular culture ${ }^{1}$. Tabloidized content caters to the popular taste as the audiences are greater in number as compared to those belonging to the elite culture. The popular media adjusts it content accordingly.

It has been debated whether it is necessary to lower the standards and quality of news content to appeal to the masses. Gans (also cited in Serazio, 2009) believes that the substance of news must not deviate from the highest of standards, even as its presentation can accommodate less erudite publics.

\section{Sensationalism}

Sensationalism is used to attract and engage the reader. Sensational content has shock value. The writer aims at increasing the curiosity and heightening the emotions of his audience.

Jones (2009) mentions the term 'McCarthyism', which he says means a particularly nasty form of destructive demagoguery. Today, the term is used to describe the unfair allegations that the press has the power to impose. This is significant as this content reaches a huge number.

One often finds the use of bold headlines, larger type and the bold use of colour on the front page of newspapers. A reader is more likely to pick up a paper that has bold attractive headlines and colour on the front page than an orthodox black and white design. Josephson (1996) notes that colour in a photo attracts the reader's eyes. An object that is relatively bigger will be seen earlier by the reader (Lundqvist and Holmqvist, 2001).

There are several prominent instances of sensational coverage of news events. The Arushi murder case in Noida, India is an appropriate example. The Supreme Court of India, in 2008, criticized the media for sensationalizing the case. 14 year old Arushi Talwar and her house help Hemraj were found murdered at the Talwar residence. The media speculated about an affair between Arushi and Hemraj and also between her father and his colleague.

In an opinion piece by Jacqueline Oark, director, Asia Pacific, International Federation of Journalists, she opines, "The media abandoned its first responsibility to truth-telling in favour of crass sensationalism. Where they could potentially have served as a window for the public into the investigation, many media outlets instead chose to reproduce and regurgitate every half-formed explanation put out by the police force." (Thakurta, 2009)

\section{Simplification}

The language quality and vocabulary is an important factor that contributes to readability. If a reader finds several incomprehensible words in the first few sentences, it is likely that he will not read any further. Therefore, in tabloidized content, simpler words and sentence structures are used to bring about clarity and to enhance readability. Jargon and other technical terms are either completely avoided or used sparingly along with simple definitions that are easier to digest. 
In a study conducted on online newspapers by a team from the University of Bristol's Intelligent Systems Laboratory and the School of Journalism at Cardiff University using the Flesch Reading Ease test ${ }^{3}$, it was concluded that tabloid content was easier to read than the content in broadsheets and that tabloids are more likely to employ sentimental language ('Algorithm Deems the Sun', Cornish, 2012).

The reader may not be interested in concentrating on the structure of the content. Rather, he may want to understand what the story is about. The idea behind this is that not many members of the audience feel the need to read news every day. Their purpose for watching news may not be to be updated about what is happening around them. The purpose may be to just stay abreast of issues and content that concern them, their immediate surroundings or to have a topic to start and maintain an engaging conversation. Therefore, it becomes important to understand that different types of audience use the media for different purposes.

Denis McQuail, Jay Blumler and Joseph Brown (cited in Richard and Turner, 2010) mentioned four categories into which media uses could be grouped. These were diversion, personal relationships, personal identity and surveillance.

The goals for media use can be grouped into the following five uses (McQuail, 2010):

1. Be informed or educated

2. Identify with characters of the situation in the media environment

3. Simple entertainment

4. Enhance social interaction

5. Escape from the stresses of daily life

Tabloidized content feeds the need for entertainment and escapism in news content. Spiteful comments, sarcasm, jest and dark humour find a way into the pages of dailies.

\section{Personalization}

To garner the interest of the readers, private matters are made public, such as an affair, an indiscretion, a hidden past. What is public, on the other hand, becomes private where content that is public has special relevance for the isolated reader (Rubery, 2009). With the personalization of news comes the focus on the individual, be it the heroic story of a survivor or the sad tale of a victim. The journalist increasingly also uses a narrative framework (Entman, 1989). The personalization of politics is a common approach by newspapers. Political news becomes entertainment and the war of words between two political candidates is given preference over the larger political scenario.

\section{Glorification Of Grief}

Another technique that is used is to glorify grief. The Press Council of India code of ethics states, "Intrusion through photography into moments of personal grief shall be avoided. However, photography of victims of accidents or natural calamity may be in larger public interest" (Press Council of India, code of ethics). A large picture that focuses on the teary eyes of the kin of a murder victim will draw more attention than a story with a mug shot of the victim. When one reads about someone's grief, it helps invoke empathy and sympathy, thus further contributing to personalization of news.

The New York Times' 'Portraits of Grief' series showed the victims of the 9/11 attacks as normal people with normal ambitions and lives (Chen et al., 2001).

The relatives of the victims of the Nithari serial murders in Noida, India were also shown crying and helpless by the Indian press.

\section{The Front Page: Selection And Grading Of News}

Tabloidization is not just about the style of writing news, it is also about the selection of news and it's grading. News related to celebrities or other popular figures, that would otherwise be termed as gossip or scandal, finds its way to the front pages of newspapers quite often these days. Such content was earlier limited to the magazine supplements or to the page 3 section $^{4}$.

Franklin (1997) names the components of a broadsheet front page:

“...tabloid-style banner headlines, funny and wisecracking headlines, large print, less text, shorter words, bigger pictures, color pictures and more of them, have become standard components of the broadsheet newspaper front page." 
Tabloidization applies to all elements of a newspaper. The front page, though, is the most visible. A study conducted by Campbell (2001) from 1999 from 1899 on seven U.S. newspapers determined the contribution of the front page elements to yellow journalism. Campbell concluded that there were some typographic features of the yellow papers, such as the appearance of multicolumn headlines, multicolumn illustrations and multiple front-page illustrations. He also stated that the keen taste for self-promotion and the tendency to assign prominence to reports about sports and society events have not been adapted by leading U.S. newspapers.

\section{Fabrication}

To make news stories interesting, journalists have been known to invent facts to support their content. The pressure to have exclusive stories has made several journalists take the risk of creating interesting and moving pieces of content. To add to that, source verification is not always placed high on the agenda. Sources can be presented as experts, complete with credentials and qualifications, news writers are able to absolve themselves from responsibility for the expert's opinions (Bird, 1992). Many a time, facts and quotes are attributed to 'a source'. Davies (2008) talks about the recycling of information received from news agencies and public relations and recycled by newspapers without any verification, a process that he terms as 'churnalism'.

Bird (2009) argues that reporters gather information through paid informants, gossip mongers and simple rumour and that journalists take the liberty to post anything without regard for verification, ethics or truth.

Foreman (2010) notes, "To fabricate, print reporters can invent scenes, characters (including composites of real characters), and quotations to embellish stories. Print photographers can manipulate images or present posed photographs as 'found moments'."

Janet Cooke (1980) from the Washington Post fabricated the story of Jimmy, an eight year old heroin addict and won the Pulitzer Prize. When it was revealed that the story was fake, she had to return the prize.

In a news item that appeared in the Hindustan Times in India, titled 'Breath Uneasy: Delhi Air Heavy with Pesticides' (Chauhan, 2007), it was reported that the usage of pesticides containing pollutants like 'Endosulfan' by farmers in Northern India was affecting human health and food chain. A complaint was filed by the Centre for Environment and Agrochemicals (CENTEGRO), Mumbai saying that the facts in the story were not correct. Since the newspaper could not establish the bonafide existence of the study, the complaint was upheld.

Boston Globe columnist Patricia Smith also had to resign after she fabricated people and quotations for her columns ('Columnist Is Ousted', Pogrebin, 1998).

There may be cases where due to the pressures exerted by the medium and certain external agencies, the journalist may forgo verification of certain facts. But press organizations around the globe consider fabrication to be a grave offence.

\section{The Visuals}

There is an increasing number of visual elements in newspaper design today as compared to a few years ago. To add to the drama, sketches and diagrams are used. Photographs are also edited and enhanced to suit the tone of the news and greater space is now reserved for and allocated to advertisements.

Modern newspapers carry many pictures that may and do invoke debates on whether print media today is keen on filtering out the 'obscene and indecent'. Photographs are often used out of context, such as news about a celebrity's engagement might show her in a swimsuit. The definition of obscenity is interpretative and therefore, newspapers can easily defend their bent towards obscene content in text and pictures.

The Supreme Court of India confirmed that the present provision of the Indian Penal Code (IPC) on obscenity is too vague to be applied in banning works (Director General, Directorate General of Doordarshan \& Ors. V. Anand Patwardhan \& Anr. 2006). "The present provision is so vague that it becomes difficult to apply. The purposeful omission of the definition of obscenity has led to attack of Section 292 of the Indian Penal Code as being too vague to qualify as a penal provision. It is quite unclear what the provisions mean. This unacceptably large grey area common in laws restricting sexual material, would appear to result not from a lack of capacity or effort on the part of drafters or legislators."

\section{Conclusion}

Bill Sloan (2001) explains that journalists who write for both tabloids and mainstream papers have understood the following:

"They recognized early on what William Randolph Hearst had figured out eighty years earlier and what practically every TV new executive and major daily editor realizes today, what qualifies as hot news has only the sketchiest relationship to pure information. For all their lofty pretenses, today's mainstream media are 
essentially just another branch of show biz. The tabloidists understood this at a time when most journalists either didn't or wouldn't admit it."

So the question that needs to be asked is why, with all the knowledge and understanding of the ethical code of journalism, are newspapers and journalists still employing tabloidist tactics? Is this profession as corruptible as any other? Is it that a few do it and others follow? Or is everybody doing it and the few who are left out bow down under pressure?

Krajicek (1998) says that the peer culture among journalists is very strong and that reporters and editors of the same and competitive organization look to one another for affirmation.

There are many newspapers that have appointed ombudsmen who cater to the grievances and complaints of the readers and provide suitable redressal options. The Organization of News Ombudsmen has found many members from all over the world.

Tabloidized content helps newspapers diversify their readership. They may be criticized by some and accepted by those who understand the medium's need to survive.

\section{Notes}

1. The term popular culture generally refers to the education and cultural values of the masses.

2. The term 'McCarthyism' originated during the 1950s to describe the anti-communist accusations and investigations by Republican U.S. Senator Joseph McCarthy of Wisconsin.

3. The core measures of the Flesch Readability ease test is word length and sentence length.

4. The term Page 3 originated from the news that appeared on the third page of the newspapers and spoke about the high society life of the upper class that included celebrities and the moneyed. News content generally contained gossip, scandals and similar sensational stories.

\section{References}

[1]. Biressi, A. and Nunn, H. (2008) (eds) The Tabloid Culture Reader. England: McGraw-Hill.

[2]. Bird, S. E. (1992) For Enquiring Minds: A Cultural Study of Supermarket Tabloids. Knoxville, TN: University of Tennessee Press.

[3]. Bird, S. E, (2009). 'Tabloidization: What is it, and Does it Really Matter?' pp.40-50 in Barbie Zelizer (eds) The Changing Faces of Journalism: Tabloidization, Technology and Truthiness. Oxon: Routledge.

[4]. Campbell, W. J. (2001) Yellow Journalism: Puncturing the Myths, Defining the Legacies. Westport, CT: Praeger.

[5]. Chauhan, C. (3 November 2007) Delhi Air Heavy with Pesticides, Says Study. Retrieved from www.hindustantimes.com/indianews/newdelhi/delhi-air-heavy-with-pesticides-says-study/article1-255463.aspx

[6]. Chen, D. W., Palma, A., Hoffman, J., Holloway, L., Ives, N., Kelley, T., McGeehan, P., O'Donnell \& M., Polgreen, L. (2001) Portraits of Grief: Glimpses of Some of the Victims of the September 11 Attacks. Retrieved from www.ddnytimes.com/national/portraits/

[7]. Cornish, D. (26 November 2012) Algorithm Deems the Sun Easiest Tabloid to Read, Comparable to CBBC. WIRED. Retrieved from www.wired.co.uk/news/archive/2012-11/26/analysis-of-news-articles

[8]. Davies, N. (2008) Flat Earth News. United Kingdom: Chatto \& Windus.

[9]. Director General, Directorate General of Doordarshan \& Ors. V. Anand Patwardhan \& Anr. (2006) Retrieved from http://judis.nic.in/supremecourt/imgs1.aspx?filename=27983

[10]. Entman, R. M. (1989) Democracy Without Citizens: Media and the Decay of American Politics. New York: Oxford University Press.

[11]. Foreman, G. (2010) The Ethical Journalist: Making Responsible Decisions in the Pursuit of News. United Kingdom: WileyBlackwell.

[12]. Franklin, B. (1997) Newszak and News Media. London; New York: Arnold

[13]. Gans, H. J. (2009). 'Can Popularization Help the News Media?' pp: 17-27 in Barbie Zelizer (eds) The Changing Faces of Journalism: Tabloidization, Technology and Truthiness. Oxon: Routledge.

[14]. Gripsrud, J. (2000). 'Tabloidization, Popular Journalism, and Democracy' pp: 285-300 in C. Sparks \& J.Tulloch (eds) Tabloid Tales: Global Debates Over Media Standards. Lanham, MD: Rowman \& Littlefield Publishers, Inc.

[15]. Jones, A. S. (2009) Losing the News: The Future of the News That Feeds Democracy. New York: Oxford University Press.

[16]. Josephson, S. (1996) 'Questioning the Power of Color' Visual Communication Quarterly, 4-7, 12.

[17]. Lundqvist, D and Holmqvist, K. (2001) 'Bigger is Better: How Size of Newspaper Advertisement and Reader Attitude Relate to Attention and Memory'. presentation at the ECEM 11, Turku, Finland.

[18]. Krajicek, D. J. (1998) Scooped! Media Miss Real Story on Crime While Chasing Sex, Sleaze, and Celebrities. New York: Columbia University Press.

[19]. Kumar, S.N. (23 October 2006) Balancing Freedom and Social Responsibility. Retrieved from www.thehindu.com/todayspaper/balancing-freedom-and-social-responsibility/article3064459.ece

[20]. McGrath, K. (2003) Newspaper research. In G. H. Stempel, D. H. Weaver \& G. C. Wilhoit (eds) Mass Communication Research and Theory (pp. 30-52). Boston: Pearson Education, Inc.

[21]. McQuail, D (2010) Mass Communication Theory: An Introduction. London: Sage Publications.

[22]. Pogrebin, R (19 June 1998). 'Columnist Is Ousted For Fabricated Articles'. New York Times. Retrieved from www.nytimes.com/1998/06/19/us/boston-columnist-is-ousted-for-fabricated-articles.html.

[23]. Press Council of India. Annual Report 2011-12. Retrieved from http://presscouncil.nic.in/Content/71_4_AnnualReports.aspx

[24]. Richard L. and Lynn H. T (2010) 'Uses and Gratifications Theory'. Introducing Communication Theory: Analysis and Application. Boston: McGraw-Hill.

[25]. Rubery, M. (2009) The Novelty of Newspapers: Victorian Fiction After the Invention of the News. New York: Oxford University Press.

[26]. Serazio, M. (2009). 'Rethinking a Villain, Redeeming a Format: The Crisis and Cure in Tabloidization' pp: 13-16 in Barbie Zelizer (eds) The Changing Faces of Journalism: Tabloidization, Technology and Truthiness. Oxon: Routledge 
[27]. Sloan, B. (2001) "I Watched a Wild Hog Eat My Baby!" A Colorful History of Tabloids and Their Cultural Impact. Amherst, NY: Prometheus Books.

[28]. Sparks, C. (2000) 'The Panic Over Tabloid News' pp: 1-40 in Colin Sparks and John Tulloch (eds) Tabloid Tales: Global Debates Over Media Standards. New York: Rowman and Littlefield.

[29]. Thakurta, P. G. (2009) Media Ethics: Truth Fairness Objectivity. New Delhi, India: Oxford University Press.

[30]. West, R. L. and Lynn, H. T (2010) 'Uses and Gratifications Theory'. Introducing Communication Theory: Analysis and Application. Boston: McGraw-Hill

[31]. Williams, K. (2003) Understanding Media Theory. London: Oxford University Press, Inc. 